Pesq. Vet. Bras. 37(9):926-930, setembro 2017

DOI: $10.1590 / \mathrm{S} 0100-736 \mathrm{X} 2017000900005$

\title{
Spontaneous poisoning by Sida carpinifolia (Malvaceae) in horses ${ }^{1}$
}

\author{
Daniele M. Bassuino², Guilherme Konradt ${ }^{2}$, Matheus V. Bianchi ${ }^{2}$, Matheus O. Reis ${ }^{2}$, \\ Saulo P. Pavarini ${ }^{2}$ and David Driemeier ${ }^{2 *}$
}

\begin{abstract}
Bassuino D.M., Konradt G., Bianchi M.V., Reis M.O., Pavarini S.P. \& Driemeier D. 2017. Spontaneous poisoning by Sida carpinifolia (Malvaceae) in horses. Pesquisa Veterinária Brasileira 37(9):926-930. Setor de Patologia Veterinária, Faculdade de Veterinária, Universidade Federal do Rio Grande do Sul, Av. Bento Gonçalves 9090, Porto Alegre, RS 91540-000, Brazil. E-mail: davetpat@ufrgs.br

Sida carpinifolia poisoning causes a chronic neurodegenerative disorder associated with lysosomal storage by indolizidine alkaloids (swainsonine). The epidemiological, clinical, pathological and lectin histochemistry findings of an outbreak of natural poisoning by S. carpinifolia in horses in Rio Grande do Sul state, Brazil, are described. Five horses from a total of 15 that were kept on native pasture with large amounts of $S$. carpinifolia presented during 90 days clinical signs of progressive weight loss, incoordination, stiff gait and ramble, in addition to exacerbated reactions and locomotion difficulty after induced movement. Four horses died, and one of them was submitted for necropsy. At necropsy, no significant gross lesions were observed. Histological findings observed in the central nervous system were characterized by swollen neurons with cytoplasm containing multiple microvacuoles; these abnormalities were more severe in the thalamus, hippocampus, cerebellum and pons. Using lectin histochemistry, the pons and hippocampus sections stained positive for commercial lectin Con-A, sWGA and WGA. This study aimed to detail S. carpinifolia poisoning in horses to be included in the differential diagnoses of neurological diseases of horses.
\end{abstract}

INDEX TERMS: Poisoning plants, Sida carpinifolia, Malvaceae, plant poisoning, horses, lysosomal storage disease, swainsonine, central nervous system.

RESUMO.- [Intoxicação natural por Sida carpinifolia em equinos.] A intoxicação por Sida carpinifolia é uma desordem neurodegenerativa crônica associada ao acúmulo lisossomal pelo alcaloide indolizidínico, denominado swainsonina. Descrevem-se os achados epidemiológicos, clínicos, patológicos e de lectina-histoquímica de um surto de intoxicação natural por S. carpinifolia em equinos no Rio Grande do Sul, Brasil. De um total de 15 equinos, cinco equinos mantidos em campo nativo com grande quantidade de S. carpinifolia apresentaram sinais clínicos de emagrecimento progressivo, incoordenação, andar rígido e deambulação, além de dificuldade de locomoção com reações exacerbadas após estímulos ao movimento em um período de 90 dias de evolução clínica.

\footnotetext{
${ }^{1}$ Received on March 9, 2016.

Accepted for publication on July 21, 2016.

${ }^{2}$ Setor de Patologia Veterinária, Departamento de Patologia Clínica Veterinária, Faculdade de Veterinária, Universidade Federal do Rio Grande do Sul (UFRGS), Av. Bento Gonçalves 9090, Porto Alegre, RS 95320-000, Brazil. *Corresponding author: davetpat@ufrgs.br
}

Quatro equinos vieram a óbito e um foi submetido ao exame de necropsia. À necropsia, não foram observadas lesões macroscópicas. Os achados histológicos observados no sistema nervoso central caracterizaram-se por aumento de tamanho dos neurônios, com citoplasma contendo microvacúolos; tais alterações foram observadas com maior intensidade em tálamo, hipocampo, cerebelo e ponte. Na lectina-histoquímica, fragmentos de ponte e hipocampo marcaram positivamente para as lectinas comerciais Con-A, $s W G A$ e WGA. Este trabalho visa alertar a ocorrência da intoxicação por S. carpinifolia em equinos, a qual deve ser incluída como diagnóstico diferencial dentre as doenças neurológicas de equinos.

TERMOS DE INDEXAÇÃO: Plantas tóxicas, Sida carpinifolia, Malvaceae, intoxicação por plantas, equinos, doença do acúmulo lisossomal, swainsonina, sistema nervoso central.

\section{INTRODUCTION}

In Brazil, more than 122 plant species poisonous for livestock have been described (Riet-Correa et al. 2009). The 
increasing number of outbreaks after the ingestion of poisonous plants by livestock is explained, in part, by the large territorial area of the country and the production system, which is predominantly extensive or semi-extensive (Pessoa et al. 2013). Sida carpinifolia is an American native plant that occurs in almost all of the national territory (Kissmann \& Groth 2000, Lorenzi 2000). In the state of Rio Grande do Sul, this plant occurs mainly in humid and shady areas, where it has already been diagnosed as a cause of poisoning in goats (Driemeier et al. 2000), ponies (Loretti et al. 2003), sheep (Seitz et al. 2005), cattle (Furlan et al. 2009, Pedroso et al. 2010), and deer (Dama dama) (Pedroso et al. 2009). The poisoning is associated with lysosomal storage of oligosaccharides caused by the indolizidine alkaloid swainsonine (Colodel et al. 2002b), which triggers the inhibition of lysosomal $\alpha$-mannosidase and $\alpha$-mannosidase II from the Golgi complex (Agamanolis 1995, Moremen 2002), thus affecting neurons (Molyneux \& James 1982, Stegelmeier et al. 1995). The poisoning results in a chronic disease with clinical signs characterized by incoordination, ataxic gait (dysmetria), head and neck tremors and frequent falls (Colodel et al. 2002a, Furlan et al. 2008). On gross examination, there are no characteristic abnormalities (Colodel et al. 2002a, Seitz et al. 2005, Furlan et al. 2008), and histological lesions consist of distention and vacuolation of the Purkinje neurons in the cerebellum, brainstem nuclei, acinar pancreatic cells, follicular epithelial cells of thyroid gland, renal tubular cells, hepatocytes and macrophages of lymphoid organs (Colodel et al. 2002a, Seitz et al. 2005, Furlan et al. 2008, 2009). The aim of this study was to describe the epidemiological, clinical, pathological and lectin histochemistry findings of an outbreak of natural poisoning by Sida carpinifolia in horses, highlighting the similarities and differences with outbreak previously described in ponies (Loretti et al. 2003).

\section{MATERIALS AND METHODS}

Epidemiological and clinical data of the condition affecting horses were obtained through field work with the farmer and veterinarian in charge. One horse was euthanized, followed by necropsy at the farm where the outbreak occurred. After gross examination, samples of multiple tissues were collected and fixed in 10\% neutral buffered formalin. After fixation for $24 \mathrm{~h}$, samples were trimmed, routinely processed for histopathological examination, embedded in paraffin, sectioned at $3 \mu \mathrm{m}$, and stained with haematoxylin and eosin (HE). Moreover, refrigerated brain and spinal cord samples underwent direct immunofluorescence testing for detection of rabies virus in a certified official laboratory.

Brain sections (cerebellum, pons, thalamus and hippocampus) were stained using lectin histochemistry (Goldstein \& Hayes 1978) with commercial lectins (Vector Laboratories, Burlingame, CA) (Chart 1) through a previously protocol described by Pedroso et al. 2010. The lectins were diluted to $5 \mathrm{mg} / \mathrm{ml}$ in PBS (phosphate buffered saline), except for Concanavalia ensiformis lectin, which was diluted to $1 \mathrm{mg} / \mathrm{ml}$. Furthermore, immunohistochemistry (IHC) using anti-glial fibrillary acidic protein (GFAP) was performed on the same sections using streptavidin-biotin-peroxidase staining with anti-glial fibrillary acidic protein (GFAP) at 1:500 and anti-S100 at 1:200 as primary antibodies. The antigens were retrieved with heat, and the reaction was revealed with 3'3-diaminobenzina (DAB) chromogen (DAKO). A brain section from a horse of the same age with no brain lesions was used as a negative control.

\section{RESULTS \\ Epidemiology and clinical signs}

The outbreak occurred on a property located in Viamão, Rio Grande do Sul, with a total area of 60 ha. The production was focused on beef buffalos, and the herd was kept on native pasture without supplementation with a total of fifteen Crioulo horses. Five horses had a common history of neurological signs and progressive weight loss, including four ten-year-old adult horses and one foal. Four of these animals died over a clinical course of 90 days and one was euthanized and subject to necropsy. The clinical signs were characterized by progressive weight loss, incoordination, stiff gait, rambling, abnormal behaviour, exacerbated reactions (Fig.1) and locomotion difficulty after induced movement (hyperesthesia). Frequently, according to the property owner, these animals were found trapped in fences or in dense brush areas. When the native pasture was inspected, a wide infestation with Sida carpinifolia along the fences and riverside was observed (Fig.2). The buffalos did not show any similar clinical signs.

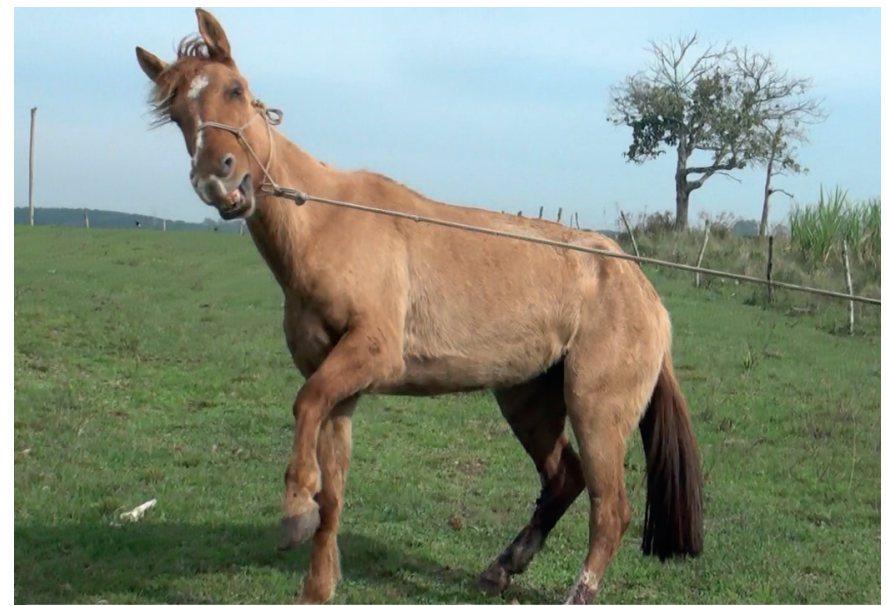

Fig.1. Spontaneous poisoning by Sida carpinifolia (Malvaceae) in horses. Horse with a poor body condition showing abnormal behaviour with exacerbated reactions after induced movement.

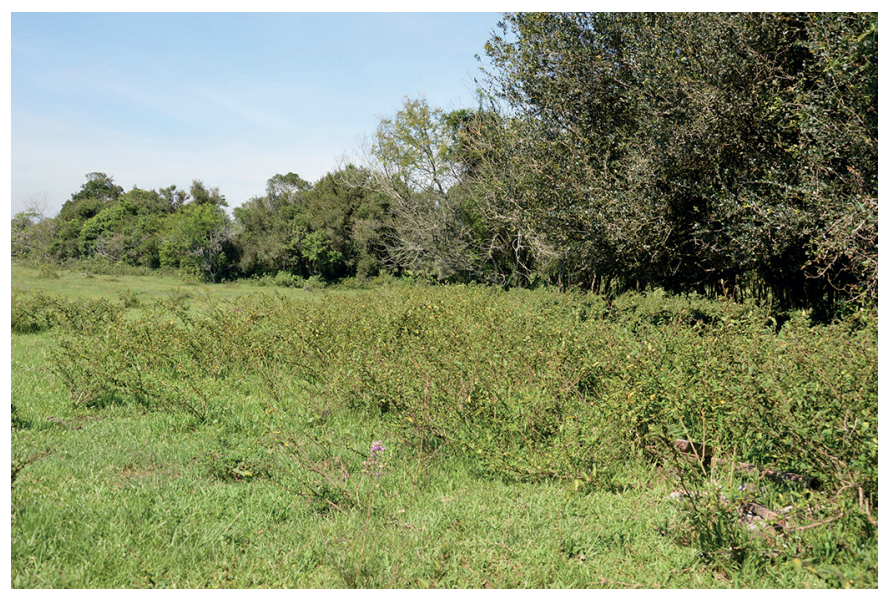

Fig.2. Spontaneous poisoning by Sida carpinifolia (Malvaceae) in horses. Horses affected by the condition were kept on a native pasture that was widely infested by Sida carpinifolia. 


\section{Pathological findings}

At necropsy, poor body condition and extensive lacerations of the skin bilaterally on the distal hindlimbs were observed. No significant gross lesions were observed during internal examination. Moderate distension of the large colon by faecal content and moderate urinary bladder distension were observed. Histologically, neurons and astrocytes from the telencephalic cortex, diencephalon, striate body, rhombencephalon, cerebellum and spinal cord were mildly swollen with fringed cytoplasm, sometimes containing multiple microvacuoles; such abnormalities were observed in varying degrees, yet they were marked in the thalamus, hippocampus (Fig.3A), cerebellum (Fig.3B) and pons. All segments of the spinal cord assessed (cervical, cervical intumescence, thoracic, lumbar, lumbar intumescence and sacral) had marked neuronal cytoplasmic vacuolization (Fig.3C). Occasionally, there were neurons with shrunken and hypereosinophilic cytoplasm (neuronal necrosis), in addition to multifocal axonal spheroids. Cerebellum sections showed Purkinje neurons layer with moderate proliferation of Bergmann astrocytes. In the mesentery celiac ganglia, trigeminal ganglia and paraspinal ganglia (Fig.3D) there was mild neuronal cytoplasmic vacuolization. Furthermore, there was marked cytoplasmic vacuolization of the thyroid follicular epithelial cells (Fig.3E) and proximal convoluted tubular cells. The liver showed moderate multifocal cholestasis and mild hepatocellular tumefaction. Direct immunofluorescence for rabies detection was negative.

\section{Lectin histochemistry and immunohistochemistry}

In lectin histochemistry of pons, cerebellum, thalamus and hippocampus sections, there was positive cytoplasmic stain in the vacuolization of neurons for commercial lectins WGA (Fig.3F), Con-A (Fig.3G) and $s$-WGA that varied from mild to marked and were highlighted more frequently in pons and cerebellum sections. In addition, there was mild to moderate positive stain for UEA I, PNA and SJA. The remaining lectins did not show any positive stain. Immunohistochemistry anti-GFAP showed moderate marking in Purkinje cells layer of cerebellum (astrogliosis). Bergmann astrocytes proliferation was highlighted by immunohistochemistry anti-S100 marking in cerebellum.

\section{DISCUSSION}

A diagnosis of Sida carpinifolia poisoning in these cases was obtained through clinical, epidemiological, histopathological and lectin findings. Lysosomal storage diseases, both hereditary and acquired, are uncommon in horses, with few descriptions in this species. These descriptions include reports of inherited neuronal ceroid lipofuscinosis (Url et al. 2001) and acquired cases of poisoning by Astralagus spp. and Oxytropis spp. in the United States of America (James \& Painter 1989) and Swainsona canascens var. horniana in Australia (Locker et al. 1980). Plants that contain swainsonine, which causes neurological disorders associated with oligosaccharide storage, are part of an important group of poisonous plants in Brazil (Oliveira et al. 2013). Sida carpinifolia is a perennial scrub from the Malvaceae family, and it is frequently found in the humid and shady areas of Southern, Southeastern and Centralwestern Brazil (Tokarnia et al. 2012). This distribution is in agreement with our epidemiological findings on the property, where $S$. carpinifolia was found predominantly in shady areas close to native brush. Loretti et al. (2003) described the clinical findings in ponies naturally poisoned by S. carpinifolia, which included stiff gait, general muscular tremors, signs of abdominal pain, rolling, moans, recumbence and death 15-20 days after introduction into
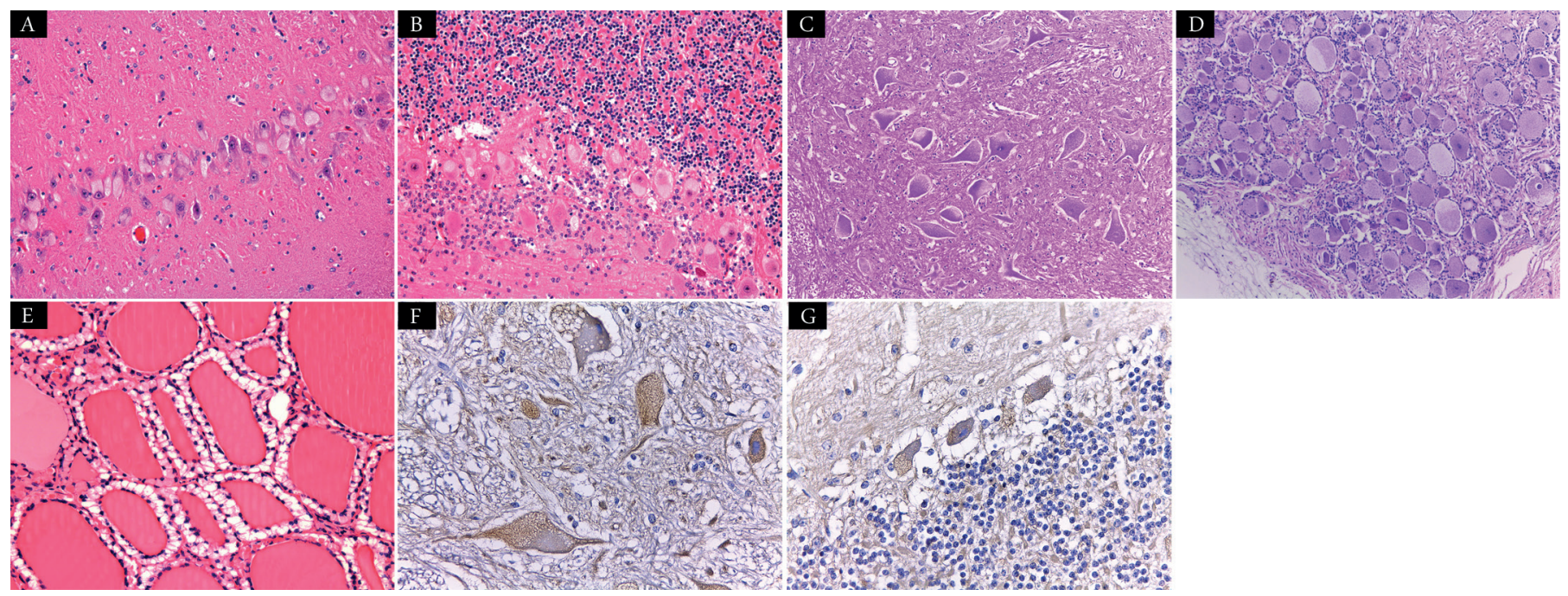

Fig.3. Spontaneous poisoning by Sida carpinifolia (Malvaceae) in horses. (A) Brain, hippocampus. Neurons were mildly swollen with multiple cytoplasmic microvacuoles. HE, 200x. (B) Brain, cerebellum. Moderate proliferation of Bergmann astrocytes in the Purkinje neuron layer, in addition to marked cytoplasmic vacuolization of Purkinje neurons. HE, 200x. (C) Spinal cord, lumbar intumescence. Marked neuronal cytoplasmic vacuolization. HE, 100x. (D) Peripheral nervous system, paraspinal ganglia. Neurons with large and vacuolated cytoplasm. HE, 100x. (E) Thyroid. Marked cytoplasmic vacuolization of thyroid folicular epithelial cells. HE, 200x. (F) Brain, pons. Lectin histochemistry positive stain in a neuron using commercial lectin WGA. DAB, 400x. (G). Brain, cerebellum. Lectin histochemistry positive stain in a neuron using commercial lectin Con-A. DAB, 400x. 
a new area with large amounts of Sida carpinifolia. Clinically, the horses described herein had abnormal behaviour with exacerbated reactions and locomotion difficulty after induced movement (hyperesthesia). However, these animals also had incoordination, stiff gait and ramble and were frequently found dead, trapped in fences or in dense brush areas. It is suggested that the clinical picture of colic is primarily the result of neurogenic dysfunction of large intestine motility due to lesions in the celiac ganglia and submucosal and myenteric plexuses (Summers et al. 1995, Rooney \& Robertson 1996). However, no gastrointestinal disorders resulting from these lesions were observed in horses in this study, as described in ponies (Loretti et al. 2003). This lack of observed symptoms may be related to the degree of injury observed in these tissues, which was classified as mild in our study. Abnormalities in coordination and behaviour are caused primarily by chronic neurodegenerative lesions triggered by the toxic active principle of the plant, which leads to oligosaccharide storage in the cytoplasm of cells from multiple tissues (Agamanolis 1995, Moremen 2002, Barros et al. 2006). The severity of the neurological signs observed is explained by the neuronal and axonal lesions developed in natural descriptions of poisoning by S. carpinifolia (Loretti et al. 2003). Pathogenesis involves a deficiency of the lysosomal enzyme $\alpha$-mannosidase, which is responsible for the catabolism of multiple glycoprotein portions; thus, it induces the lysosomal storage of a wide range of oligosaccharides (Daniel et al. 1989, Jolly \& Walkley 1997). The disease induced by the toxin (swainsonine) differs from the inherited condition because the toxin also causes the inhibition of mannosidase II produced in the Golgi complex, in addition to the inhibition of $\alpha$-mannosidase (Elbein et al. 1989). It has been shown experimentally that the clinical evolution and clinical signs are related to the time of ingestion and the amount of plant that is consumed (Driemeier et al. 2000, Colodel et al. 2002a, Seitz et al. 2005, Furlan et al. 2008). The clinical evolution for these horses was 90 days, which differs from what has been described in ponies, wherein the toxicosis had a peracute to acute course. Feed restriction was probably the factor that induced the ponies to eat the poisonous plant in that case (Loretti et al. 2003).

The necropsy findings in cases of poisoning by $S$. carpinifolia are not significant (Colodel et al. 2002a, Seitz et al. 2005, Barros et al. 2006, Furlan et al. 2008). In this case, there was only moderate distension of the large colon by faecal material, which was also described in ponies poisoned by S. carpinifolia (Loretti et al. 2003). Microscopic lesions in the brain and spinal cord were mainly characterized by marked cytoplasmic vacuolization of neurons and astrocytes, with few necrotic neurons and axonal spheroids. There was also moderate proliferation of Bergmann astrocytes in the cerebellum, moderate vacuolization of thyroid follicular epithelial cells and proximal convoluted tubular cells, and mild vacuolization of hepatocytes. These were similar to what has already been described in natural and experimental poisoning in cattle (Furlan et al. 2008, Pedroso et al. 2010), sheep (Seitz et al. 2005), goats (Driemeier et al. 2000, Colodel et al. 2002a) and ponies (Loretti et al. 2003). Other authors have also described cytoplasmic vacuolization of acinar pancreatic epithelial cells (Driemeier et al. 2000, Seitz et al. 2005, Furlan et al. 2008, Pedroso et al. 2010, 2012).

Lectins are proteins or glycoproteins of non-immune origin that bind reversibly to specific residues of carbohydrates (glycoproteins, glycolipids and glycosaminoglycans) (Goldstein et al. 1980, Lis \& Sharon 1998). Lectin histochemistry analysis may detect some substances in a tissue where a lesion has occurred and establish a correlation between the presence, quantity, severity and extent of a process (Costa et al. 2013). The efficiency of this analysis has been proven in previous studies through the detection of complex substances containing sugars, related or not to storage diseases, such as glycoproteinosis (Driemeier et al. 2000, Armién et al. 2007) and glycolipidoses (Alroy et al. 1986, Murname et al. 1989). The brain sections undergoing this analysis in this study had moderate to marked cytoplasmic staining in neurons when using Triticum vulgaris (WGA) and Succinyl Triticum vulgaris (sWGA), which indicates the expression of $\mathrm{B}-\mathrm{D}-\mathrm{N}$-acetylglucosamine and acetylneuraminic acid. Similar findings were observed when Concanavalia ensiformis (Con- $A$ ) was employed, which is used as a specific lectin for $\alpha$-D-mannose and $\alpha$-Dglucose (Goldstein \& Hayes 1978, Goldstein et al. 1980). The mild to moderate staining for UEA I, PNA and SJA lectins observed here has been described in goats poisoned by the same plant (Driemeier et al. 2000) and has also been shown in tissues without lesions (Wood et al. 1981, Viejo et al. 1994, Driemeier et al. 2000). IHC anti-S100 has highlighted the increasing number of Bergmann astrocytes in the cerebellum, in addition to a higher expression of GFAP. Bergmann's glia is a specialized population of astrocytes that occurs in the Purkinje cell layer of the cerebellum (Cantile \& Youssef 2016). The increasing number of Bergmann astrocytes has been described in cases of primary loss of Purkinje cells with secondary depletion of the molecular and granular layers (Mari et al. 2014), as well as by other authors in poisonings by plants containing swainsonine as the primary toxin (Armién et al. 2011, Takeda et al. 2014).

Lysosomal storage disease occurred in horses through the natural ingestion of $S$. carpinifolia, causing progressive neurological signs and a characteristic cytoplasmic vacuolization of neurons and astrocytes, which showed marked positive staining for Con-A, sWGA and WGA lectins.

\section{REFERENCES}

Agamanolis D.P. 1995. The pathology of lysosomal storage diseases. Pathol. Annu. 30:247-285.

Alroy J., Ucci A.A., Goyal V. \& Woods W. 1986. Lectin histochemistry of glycolipid storage diseases on frozen and paraffin-embedded tissue sections. J. Histochem. Cytochem. 34(4):501-505.

Armién A.G., Tokarnia C.H., Peixoto P.V. \& Frese K. 2007. Spontaneous and experimental glycoprotein storage disease of goats induced by Ipomoea carnea subsp. fistulosa (Convolvulaceae). Vet. Pathol. 44:170-184.

Armién A.G., Tokarnia C.H., Peixoto P.V., Barbosa J.D. \& Frese K. 2011. Clinical and morphologic changes in ewes and fetuses poisoned by Ipomoea carnea subspecies fistulosa. J. Vet. Diagn. Invest. 23:221-232.

Barros C.S.L., Driemeier D., Dutra I.S. \& Lemos R.A.A. 2006. Doenças do Sistema Nervoso de Bovinos no Brasil. Vallée, São Paulo, p.21-28. 
Cantile C. \& Youssef S. 2016. Nervous System, p.250-406. In: Jubb K.V.F., Kennedy P.C. \& Palmer N. (Eds), Pathology of Domestic Animals. Vol.1. 6th ed. Elsevier, St Louis.

Colodel E.M., Driemeier D., Loretti A.P., Gimeno E.J., Traverso S.D., Seitz A.L. \& Zlotowski P. 2002a. Aspectos clínicos e patológicos da intoxicação por Sida carpinifolia (Malvaceae) em caprinos no Rio Grande do Sul. Pesq. Vet. Bras. 22:51-57.

Colodel E.M., Gardner D.R., Zlotowski P. \& Driemeier D. 2002b. Identification of Swainsonine as a glycoside inhibitor responsible for Sida carpinifolia poisoning. Vet. Hum. Toxicol. 44:177-178.

Costa S.Z.R., Nespoli P.B., Bezerra Jr P.S., Nogueira V.A., Driemeier D., Boabaid F.M., Peixoto P.V., Armién A.M. \& França T. 2013. Avaliação lectina-histoquímica de fígado e rim de ovinos com fotossensibilização causada por Brachiaria decumbens. Pesq. Vet. Bras. 33(8):955-962.

Daniel P.F., Warren C.D., James L.F. \& Jolly R.D. 1989. A comparison of swainsonine-induced and genetic a-mannosidosis in Aberdeen Angus cattle, p.331-343. In: James L.F., Elbein A.D., Molyneux R.J. \& Warren C.D. (Eds), Swainsonine and Related Glycosidase Inhibitors. Iowa State University Press, Ames, Iowa.

Driemeier D., Colodel E.M., Gimeno E.J. \& Barros S.S. 2000. Lysosomal storage disease caused by Sida carpinifolia in goats. Vet. Pathol. 37:153-159.

Elbein A.D. 1989. The effects of plant indolizidine alkaloids and related compounds on glycoprotein processing, p.155-187. In: James L.F., Elbein A.D., Molyneux R.J. \& Warren C.D. (Eds), Swainsonine and Related Glycosidase Inhibitors. Iowa State University Press, Ames, Iowa.

Furlan F.H., Lucioli J., Veronezi L.O., Traverso S.D. \& Gava A. 2008. Intoxicação experimental por Sida carpinifolia (Malvaceae) em bovinos. Pesq. Vet. Bras. 28:57-62.

Furlan F.H., Lucioli J., Veronezi L.O., Medeiros A., Barros S.S., Traverso S.D. \& Gava A. 2009. Spontaneous lysosomal storage disease caused by Sida carpinifolia (Malvaceae) poisoning in cattle. Vet. Pathol. 46:343-347.

Goldstein I.J. \& Hayes C.E. 1978. The lectins: carbohydrate binding proteins of plants and animals. Adv. Carbohydr. Chem. Biochem. 35:127-340.

Goldstein I.J., Hayes R.C., Monsigny M., Osawa T. \& Sharon N. 1980. What should be called a lectin? Nature 285:66.

James L.F. \& Painter K.E. 1989. Locoweed poisoning in livestock, p.23-38. In: James L.F., Elbein A.D., Molyneux R.J. \& Warren C.D. (Eds), Swainsonine and Related Glycosidase Inhibitors. Iowa State University Press, Ames, Iowa.

Jolly R.D. \& Walkley S.U. 1997. Lysosomal storage diseases of animals: an essay in comparative pathology. Vet. Pathol. 34:527-548.

Kissmann K.G. \& Groth D.G. 2000. Plantas Infestantes e Nocivas. Tomo III. BASF S.A., São Bernardo do Campo, SP. 722p.

Lis H. \& Sharon N. 1998. Lectins: carbohydrate-specific proteins that mediate cellular recognition. Chem. Rev. 98:637-674.

Locke K.B., McEwan D.R. \& Hamdorf I.J. 1980. Experimental poisoning of horses and cattle with Swainsona canascens var. horniana. Aust. Vet. J. 56:379-383.

Lorenzi H. 2000. Plantas Daninhas do Brasil: terrestres, aquáticas, parasitas, tóxicas e medicinais. 5th ed. Plantarum Ltda, Nova Odessa, SP. 339p.

Loretti A.L.P., Colodel E.M., Gimeno E.J. \& Driemeier D. 2003. Lysosomal storage disease in Sida carpinifolia toxicosis: an induced mannosidosis in horses. Equine Vet. J. 35:434-438.
Mari C., Bassuino D.M., Wouters A.T.B., Bandinelli M.B., Driemeier D. \& Pavarini S.P. 2014. Abiotrofia cerebelar em um canino American Staff ordshire Terrier adulto no Brasil. Acta Scient. Vet. 42(1):52.

Molyneux R.J. \& James L.F. 1982. Loco intoxication: Indolizidine alkaloids of spotted locoweed (Astragalus lentiginosus). Science 216:190-191.

Moremen K.W. 2002. Golgi $\alpha$-manosidase II deficiency in vertebrate systems: implications for asparagines-linked oligosaccharide processing in mammals. Biochem. Biophys. Acta 1573:225-235.

Murname R.D., Ahern-Rindell A.J. \& Prieuer D.J. 1989. Lectin histochemistry of an ovine lysosomal storage disease with deficiencies of betagalactosidase and alfa-neuraminidase. Am. J. Pathol. 135(4):623-630.

Oliveira C.A., Riet-Correa G. \& Riet-Correa F. 2013. Intoxicação por plantas que contêm swainsonina no Brasil. Ciência Rural 43(4):653-661.

Pedroso P.M.O., Von Hohendorf R., Oliveira L.G.S., Schmitz M., Cruz C.E.F. \& Driemeier D. 2009. Sida carpinifolia (Malvaceae) poisoning in fallow deer (Dama dama). J. Zoo Wildl. Med. 40:583-585.

Pedroso P.M.O., Oliveira L.G.S., Cruz C.E.F., Soares M.P., Barreto L.R.B. \& Driemeier D. 2010. Doença do armazenamento lisossomal induzida pelo consumo de Sida carpinifolia em bovinos do Rio Grande do Sul. Pesq. Vet. Bras. 30(10):833-838.

Pedroso P.M.O., Colodel E.M., Seitz A.L., Correa G.L.F., Soares M.P. \& Driemeier D. 2012. Pathological findings in fetuses of goats and cattle poisoned by Sida carpinifolia (Malvaceae). Pesq. Vet. Bras. 32(3):227-230.

Pessoa C.R.M., Medeiros R.M.T. \& Riet-Correa F. 2013. Importância econômica, epidemiologia e controle das intoxicações por plantas no Brasil. Pesq. Vet. Bras. 33(6):752-758.

Riet-Correa F., Pfister J., Schild A.L., Medeiros R.M. \& Dantas A.F.M. 2009. Poisonings by Plants, Mycotoxins and Related Substances in Brazilian Livestock. Pallotti, Santa Maria. 246p.

Rooney J.R. \& Robertson J.L. 1996. Nervous system, p.308-343. In: Rooney J.R. \& Robertson J.L. (Eds), Equine Pathology. Iowa State University Press, Ames, Iowa. 482p.

Seitz A.L., Colodel E.M., Schmitz M., Gimeno E.J. \& Driemeier D. 2005. Use de lectin histochemistry to diagnose Sida carpinifolia (Malvaceae) poisoning in sheep. Vet. Rec. 156:386-388.

Summers B.A., Cummings J.F. \& De Lahunta A. 1995. Veterinary Neuro-Pathology. Mosby, St Louis. 527p.

Stegelmeier B.L., Molyneux R.J., Elbein A.D. \& James L.F. 1995. The lesions of locoweed (Astragalus mollissimus), swainsonine and castanospermine in rats. Vet. Pathol. 32:289-298.

Takeda S., Tanaka H., Shimada A., Morita T., Ishihara A., Adilbish A., Delgermaa B. \& Gungaa 0. 2014. Cerebellar Ataxia Suspected to be Caused by Oxytropis glabra Poisoning in Western Mongolian Goats. J. Vet. Med. Sci. 76(6):839-846.

Tokarnia C.H., Brito M.F., Barbosa J.D., Peixoto P.V. \& Döbereiner J. 2012. Plantas Tóxicas do Brasil. $2^{a}$ ed. Editora Helianthus, Rio de Janeiro. 566p.

Url A., Bauder B., Thalhammer J., Nowotny N., Kolodziejek J., Herout N., Fürst S. \& Weissenböck H. 2001. Equine neuronal ceroid lipofuscinosis. Acta Neuropathol. 101:410-414.

Viejo T.F., Peña M.A. \& Puerta F.J. 1994. Lectinbinding patterns in the development of the cerebellum. Anat. Embryol., Berl. 189:169-179.

Wood J.G., Byrd F.I. \& Gurd J.W. 1981. Lectin cytochemistry of carbohydrates on cell membranes of rat cerebellum. J. Neurocytol. 10:149-159. 